\title{
Türk Basınında Vietnam Savaşı: Ulus Gazetesi Örneği
}

\author{
Arş. Gör. Mehtap ŞİMŞEK*
}

\begin{abstract}
$\ddot{O Z Z T}$
ABD ile Kuzey Vietnam arasında 1965 yılında başlayıp, 1973 yılında sona eren "Vietnam Savaşı", tüm dünya basınında olduğu gibi Türk basinında da yankı bulmuştur. Biz bu makalemizde Ulus Gazetesi örneğini ele alarak, Vietnam Savaşıı'nin Türk basınına yansimasını Ulus Gazetesi çerçevesinde incelemeye çallşstık. Bu bağlamda savaşın başından sonuna kadar meydana gelen gelişmeleri gazetenin nasıl ele aldığını değerlendirmeye çalıştık.
\end{abstract}

Anahtar Kelimeler: Vietnam, ABD, Basin, Ulus Gazetesi

\section{ABSTRACT}

"Vietnam War" was between USA and North Vietnam that started in 1965 finished in 1973, to have repercussions in Turkish Media like as World Media. In this article we studied to analysis Vietnam War's to be a reflex on Turkish Media as part of Ulus Newspaper. In this context, we studied to evaluation how to approach the Ulus Newspaper's to occur events, through the war.

Key Words: Vietnam, USA, Media, Ulus Newspaper

\section{GİRİ̧̧}

Söz konusu çalışma iki ayaklı bir araştırmaya dayanmaktadır. Daha açık bir ifadeyle çalışmanın iki öznesi bulunmaktadır. Birincisi Vietnam Savaşı, ikincisi ise Ulus Gazetesi ve gazetenin bu savaşa bakış açısıdır. Bu bağlamda araştırmanın başında, hem Vietnam Savaşı'nın hem de Ulus Gazetesi'nin tarihi gelişimi hakkında bilgi vermek yerinde olacaktır.

\footnotetext{
*Ankara Üniversitesi Türk İnkılap Tarihi Enstitüsü.
} 


\section{Vietnam Savașının Tarihi Gelişsimi}

Vietnam, Güneydoğu Asya'da kıyısı olan bir ülke olup, 329.566 km lik bir yüzölçümüne sahiptir. Vietnam, kuzeyde Çin Halk Cumhuriyeti, batıda Laos, Kamboçya ve Tayland Körfezi, güney ve doğuda Güney Çin Denizi ve Tokin Körfezi ile çevrilidir. Nüfusu, bugün 80 milyonu bulan Vietnam'ın başkenti Hanoi'dir. ${ }^{1}$ Vietnam verimli topraklara ve zengin yer altı kaynaklarına sahip bir ülkedir.

Vietnam çok uzun süre Çin egemenliği altında yaşamıştır. 19. yüzyılda, Asya'nın diğer bazı ülkeleri gibi, Vietnam da Batılıların istilasına uğramıştır. Deniz aşırı pazarlara duyduğu gereksinim ve Asya'da bir yer edinme gayesiyle Fransızlar, 1858 'de Vietnam'1 işgal etmişlerdir. ${ }^{2}$

1930-31 yıllarına gelindiğinde Vietnam halkı yavaş yavaş ayaklanmaya ve bağımsızlık mücadelesine başlamıştır. ${ }^{3}$

Vietnam mücadelesinin başlangıc1 1940'a kadar uzanır. Japonlar 1940 yılında Vietnam'a girmişlerdir. Fransızlardan sonra bir de Japonların Vietnam'a yerleşmesi, Vietnam'da bağımsızlık için çalışan bütün grupları birleştirmiştir. $\mathrm{Bu}$ birleşimden oluşan örgütün ad1 "Viet-Minh" olarak adlandırılmıştır. ${ }^{4}$

Japonya'nın 1945 yılında teslim olması üzerine komünist lider Ho Şi Minh, Vietnam'ın kuzey bölümünde bir cumhuriyet kurmuştur. Ho Şi Minh kuvvetleri ile Fransız birlikleri arasında çok şiddetli çarpışmalar olmuş ve nihayetinde Viet-Minh savaşçıları, 1954 yılında Fransızları Dien Bien Phu'yu geri alarak büyük bir yenilgiye uğratmış ve Vietnam'dan çıkmalarını sağlamışlardır. ${ }^{5}$

1954 yılı Temmuz'unda 14 ulusun katıldığ bir konferans toplanmış ve Vietnam'ın ikiye bölünmesi kabul edilmiştir. Antlaşmanın birinci maddesinde her ne kadar 17. paralelin hiçbir zaman Vietnam'1 ikiye böldüğü anlamına gelmeyeceği belirtilmiş ise de, gerçekte Vietnem bu antlaşma ile resmen ikiye bölünmüştür. ${ }^{6}$ Kuzey'de Ho Şi Minh önderliğinde ve Çin desteğinde bir komünist yönetim kurulmuştur. Güney'de kurulan devleti ise İngiltere ve ABD desteklemiştir. Bunun dışında 1954 Cenevre Antlaşması

\footnotetext{
1 Nusret Özselçuk, Ana Hatlarıyla Vietnam Savaşları ve Alınan Dersler, Genelkurmay Askeri Tarih ve Stratejik Etüt Başkanlığı Yayınları, Ankara 1979, s.5.

${ }_{3}^{2}$ Refik Özdek, Vietnam Çıkmazı, Yağmur Yayınevi, İstanbul 1968, s.17.

${ }^{3}$ Oral Sander, Siyasi Tarih 1918-1994, İstanbul, 1998, s.257.

4 Mustafa Mutlu, Vietnam'dan Körfez Savașı'na Uluslararası Uyușmazlıklarda Kamuoyu Oluşumu, Basılmış Doktora Tezi, İstanbul Üniversitesi 2001, s.217.

5 Jonathan Neale, Doğan Tarkan, Amerikan Savașı Vietnam 1960- 1975, İstanbul 2004, s. 105.

${ }^{6}$ Özselçuk, a.g.e., s.30.
} 
ile Vietnam ile birlikte, Çin Hindi'ndeki öteki devletler, Laos ve Kamboçya da bağımsızlıklarına kavuşmuşlardır. ${ }^{7}$ Anlaşma gereğince 1956'da uluslararası bir komisyon gözetiminde yapılacak seçimler sonucunda birleşik bir hükümet kurulması kararlaştırılmıştır. Ancak anlaşmayı onaylamayı geciktiren Güney Vietnam, ABD desteğine dayanarak seçimlere karş1 çıkmaya başlamış ve birleşmeyi imkansız hale getirmiştir. Zaten ABD, daha başından konferansa karşı ters bir tavır alarak birleşik bir Vietnam'a özgürlük tanıyacak herhangi bir çözüme temelden karşı olduklarını belirtmişlerdir. ${ }^{8}$

Anlaşma sonrasında Kuzey Vietnam Çin, SSCB ve öteki sosyalist devletlerin büyük yardım ve desteğini görmüştür. Güney Vietnam'da ise devlet başkanlığını üstlenen Diem, komünizmin Asya'da yayılmasından korkan ABD'nin ekonomik ve askeri yardımına güvenerek otoriter bir düzen kurmaya çalışmıştır.'

1 Kasım 1963'te düzenlenen askeri darbede Diem öldürülmüştür. O dönemde darbeyi ABD'nin yaptığ 1 söylentileri yayılmıştır ve daha sonraları bu söylentilerin gerçek olduğu yani darbeyi ABD'nin yaptırdığ 1 kanıtlarıyla doğrulanmıştır. ${ }^{10} \mathrm{Bu}$ arada ABD Başkanı John F.Kennedy Dallas'ta 22 Kasım 1963'te uğradığ 1 bir suikastla öldürülmüş, Kennedy'in "Vietnam Politikası" el değiştirmek zorunda kalmıştır. Kennedy'nin yerine başkan olan yardımcisı Lyndon B.Johnson, onun Vietnam meselesini kendine miras bıraktığını savunarak dört elle bu meseleye sarılmıştır.

Başkan Johnson, 1964 yılı Ağustos'unda Kuzey Vietnam devriye botlarının Tonkin Körfezinde seyreden ABD destroyeri "Maddox"a ateş açtığı iddiasıyla ABD Deniz Kuvvetleri uçaklarına Kuzey Vietnam'1 bombalama emri vermiştir. ${ }^{11}$

Bu arada Kuzey Vietnam ve Vietkong birliklerinin Şubat 1968'de 30 il merkezine karşı başlattığı "Tet Saldırısı" Güney Vietnam ve ABD'li birliklere büyük kayılar verdirmiştir.

Tet Saldırısı Vietnam Savaşı'nda bir dönüm noktası olmuştur. Askeri bir zaferin imkansız olduğunu anlayan ABD yönetimi, Mayıs 1968'de Hanoi ile görüşme masasına oturmuştur.

${ }^{7}$ Fahir Armaoğlu,, 20. Yüzyıl Siyasi Tarihi (Cilt 1-2:1914-1995), Alkım Yayınları, İstanbul 1999, s.674.

${ }^{8}$ Özselçuk, a.g.e., s.27.

${ }^{9}$ Mutlu, a.g.e., s.218.

${ }^{10}$ V.N. Giap, Vietnam Halk Savaşı, Ankara 1998, s.213

${ }^{11}$ Ana Britannica Ansiklopedisi, İstanbul 1994, Cilt 31, Hürriyet Yayınları, s.229. 
Tet Saldırısından sonra ABD kamuoyunun resmen savaş ilan edilmeden sürdürülen Vietnam Savaşı'na karşı tepkisi yükselmeye başlamıştır. Özellikle "Pentagon Belgeleri"nin yayınlanması, ayrıca ABD birliklerinin "My Lai" köyünde Vietnaml sivilleri toptan katletmesi haberleri kamuoyunu sarsmıştır. Bu arada ABD Başkanı Johnson, televizyonda yaptığı konuşmada başkanlık seçimlerinde yeniden aday olmayacağını açıklayarak herkesi şaşırtmıştır. Yapılan seçimlerde Cumhuriyetçi parti adayı Richard M.Nixon ABD başkanı seçilmiştir ve böylece ABD'nin Vietnam politikası bir kez daha yön değiştirmiştir. Nixon'un başkan seçilmesi kazanılması imkansız bir savaşı bitirmek için ABD’ye yeni bir firsat sunmuştur. ${ }^{12}$

Nixon yönetimi, Güney Vietnam ordusunun kendi başına savaşı sürdürmesini sağlayacak önlemleri alarak kendi askerini yavaş yavaş oradan çekme politikasını benimsemiştir. $\mathrm{Bu}$ politikası "Vietnamlılaştırma" politikası olarak adlandırılmıştır. Nixon'un amacı Kuzey Vietnamlıları barış görüşmeleri için masaya oturmaya zorlamak olmuştur. ABD birlikleri bu plan çerçevesinde yavaş yavaş Vietnam' dan çekilmeye başlamıştır.

$\mathrm{Bu}$ arada, Paris'te başlayan barış görüşmeleri bir anlaşmayla sonuçlanmıştır. Buna göre; 28 Ocak 1973'ten itibaren Kuzey ve Güney Vietnam'da ateşkes yürürlüğe girecek, bütün ABD kuvvetleri çekilecek, üsler sökülecek, bütün savaş tutsakları serbest bırakılacak, bölge barışı uluslararası kuvvetlerce korunacak, Güney Vietnam'1n kendi kaderini tayin etme hakkı verilecekti. Bu anlaşmaya, Haziran 1973'de 14 maddelik ikinci bir anlaşma eklenmiştir. Ağustos'ta ABD Kongresi ABD'nin Çin Hindi'nde yeni askeri etkinliklere girişmesini yasaklamıştır.

Ateşkes anlaşmasına rağmen çarpışmalar kesilmemiştir. Güney Vietnam 1974'te artık savunamadığı mevzileri terk etmeye başlamıştır. Kuzey Vietnam'ın beklenen saldırısı Ocak 1975'te başlamıştır. Kuzey Vietnam birlikleri ülkenin orta kısımlarına kadar ulamıştır. Kıyı kentler birbiri ardına terk edilmiştir. Güney Vietnam Devlet Başkanı Thieu, 21 Nisan'da istifa ederek Tayvan'a sığınmıştır. Güney Vietnam hükümetinden geriye kalanlar 30 Nisan'da kayıtsız şartsız teslim olurken, Kuzey Vietnam birlikleri hiçbir direniş görmeden Saygon'a girmiştir. Geçici bir askeri yönetimin kurulmasından sonra, 2 Temmuz 1976'da ülke resmen Vietnam Sosyalist Cumhuriyeti adıyla yeniden birleşmiş ve Hanoi başkent olmuştur. ${ }^{13}$

\footnotetext{
${ }^{12}$ Mutlu, a.g.e., s.221.

${ }^{13}$ Mutlu, a.g.e., s.222.
} 


\section{Ulus Gazetesi'nin Yorumuyla Vietnam Savaşı}

Ulus gazetesi, eski Hakimiyeti Milliye Gazetesi'nin devamı olan günlük ulusal gazete idi. Ulus 14 Eylül 1919'da yayına başlayan gazetenin kurucusu Mustafa Kemal Atatürk'tür. Başlığının altında "Adımız andımızdır" yazar. ${ }^{14}$ CHP'nin yayın organı olan Ulus, Aralık 1953'de Demokrat Parti tarafindan CHP'nin mal varlıklarına el konulmasıyla kapatılmıştır. 1954'de Yeni Ulus adıyla yayınına devam etmiştir. 1954'te adı Halkçı olmuştur, 1955'de yeniden Ulus adını almıştır. 1971 'de adı Barıș olarak değiştirilmiştir. ${ }^{15}$

Biz bu çalışmamızı yaparken Ulus Gazetesi ile ilgili şu sorulara cevap aradik:

Haber kaynakları nelerdir? Haberlerin doğruluk derecesi nedir? Savaşın başından sonuna kadar verdiği haberlerde tutarlı kalabilmiş midir? Tarafsız mıdır? Yoksa yanlı ve yönlendirici haberler vermiş midir? Savaşın gidişatı ve sonuçlanması ile ilgili isabetli yorumlar yapılabilmiş midir? Verdiği haberlerin sıklığına göre Türk Kamuoyunun savaşla ne kadar ilgilendiğini ortaya koyabilir miyiz?

$\mathrm{Bu}$ sorular çerçevesinde gazetenin 1964-1973 yılları arasındaki yayınlarını taradık. Yukarıda da belirttiğimiz gibi gazete 1971 yılından sonra yayın hayatına "Barış Gazetesi" olarak devam ettiğinden, 1971-1973 yıllarını Barış Gazetesi ile tamamladık. Barış Gazetesi, Ankara, İstanbul, Samsun ve Mersin gibi illerde çıkan yerel bir gazete görünümü vermektedir. Biz gazetenin 1971-1973 yılları arasındaki Ankara baskısını inceledik.

\section{a. Savaşın Başlaması}

Savaşın başlaması gazetede ayrıntılı olarak verilmiştir. Yaklaşı bir ay boyunca her gün savaşla ilgili haberler çıkmıştır. Savaş haberleri Kıbrıs Sorununun gündemde olmasından dolayı bir süre kesintiye uğramıştır.

Savaşın kamuoyunu çok ilgilendirdiğini gazetenin verdiği haberlerin içeriğinden anlayabiliyoruz. O zamana kadar pek bilinmeyen Vietnam, verilen haberlerle tanıtılmaya çalışılmıştır. ${ }^{16}$

Haberler genelde tarafsız olarak verilse de ilk zamanlardaki haberler ABD'yi haklı bulur yöndedir. Örneğin "Ankara Hareketi Haklı Buluyor" başl1klı haberde şu ifadelere yer verilmiştir: "İnönü, Satır, Erkin, Sunay ve

\footnotetext{
${ }^{14}$ Komisyon, A'dan Z'ye Kurtuluş Savaşı ve Atatürk Dönemi, Boyut Yayınları, İstanbul 2005, s.847.

${ }_{15}$ Uygur Kocabaşoğlu, “Cumhuriyet Dergiciliğine Genel Bir Bakış”, Türkiye'de Dergiler ve Ansiklopediler 1849-1984, Gelişim Yayınları, İstanbul 1984, s.12. 6 “İkiye Bölünen Ülke”, Ulus Gazetesi , 6 Ağustos 1964.
} 
yüksek rütbeli subaylarla görüștü. Bu görüşmelerde Kıbrıs meselesi, dünya politikasında son gelişmeler ve Vietnam olayı gözden geçirilmiştir.

...Öteden beri Güney Doğu Asya'daki komünist kuvvetlerin dünya barını tehdit ettiği görüşü etrafında birleşmiş durumdadırlar...Bir hür dünya devleti olan Türkiye de, bu gibi hallerde, diplomatik münasebetlerle bağ 1 bulunduğu Güney Vietnam'ı ve dünya barışının desteklenmesi hususunu daima savunmuştur.

...Ancak, Türk kamuoyu, bu konuda Amerika'nın tutumunu onaylamakla beraber, Kuzey Vietnam olayları ile bizim haklı davamız olan Kıbrıs meselesi arasında bir benzerlik ve yakınlık bulunmaktadır."17

Savaşın tarafi olan Kuzey Vietnam'ın komünist devletlerce desteklenmesi gazeteye göre önemli bir durum olarak görülmüş ve haberlerde genelde büyük komünist devletlerin yayınladıkları basın haberlerine yer verilmiştir. Mesela Çin'in yaşanan olaylara ağırlığını koyduğu haberlerde ayrıntılı olarak verilmiştir. ${ }^{18}$

Güney Vietnam'ın Türkiye'den yardım istediği haberi de ayrıntılı olarak gazetenin haberlerine yansımıştır. ${ }^{19} \mathrm{Bu}$ haberin ayrıntılarına bakıldığında gazetenin Güney Vietnam'a daha yakın bir çizgide olduğu göze çarpmaktadır.

Kısaca şunu diyebiliriz ki, savaşın başladığ gazete savaşla ilgili, mümkün olduğunca düzenli olarak okuyucularına bilgi vermiştir. ${ }^{20}$ Ancak verdiği haberlerde çok fazla yorum yapma gereği duymadan, haberleri olduğu gibi vererek okuyucunun yorumuna bırakmıştır.

\section{b. Savaşın Şiddetlenmesi}

1965 yılının Şubat ayında ABD Kuzey Vietnam'a saldırılarını artırmış ve savaş şiddetlenmiştir. Bunun paralelinde gazete savaşla ilgili haberlere hemen hergün ayrıntılı olarak yer vermiştir.

Gazete tarafsılık çizgisinden çıkmamaya özen gösterse de bazı haberlerle ABD'nin haksız olduğunu düşündürecek olaylara yer vermiștir. Örneğin "Vietnam'da Neler Oluyor" başlıklı haberde Güney Vietnam savaşlarında enteresan haberlere yer vermiş ve Amerika'nın Güney

\footnotetext{
17 “Ankara ABD’yi Haklı Buluyor”, Ulus Gazetesi, 7 Ağustos 1964.

18 "Kızıl Çin Vietnam'a Yapılan Bir Saldırıyı Kendisine Yöneltilmiş Saydığını Belirtti”, Ulus Gazetesi, 7 Ağustos 1964

19 "Güney Vietnam Türkiye'den Yardım İstiyor”, Ulus Gazetesi, 8 Ağustos 1964.

${ }^{20}$ Gazete genelde savaşa ilgi duyup, düzenli olarak haber vermeye çalıșmıștır ancak Türkiye gündemini meşgul eden daha önemli olaylar olduğu zaman (Kibrıs Meselesi gibi), savaşla ilgili haber vermeye bir süre ara vermiştir.
} 
Vietnam'daki varlığının halk tarafından da hoş karşılanmadığını yaşanan örnek olaylarla dile getirmiştir. "...içkili bir Amerikan askeri, şoförü ile ücret üzerinde münakaşa eder ve şoförü yere itip karanlıkta kaybolur. Şoför yerden kalkar, tozlarını silkeler ve Amerikalının arkasından "Bir gün" diye söylenir.

... İçinde iki Amerikalı idareci bulunan lüks bir Amerikan arabasının Vietnamlı şoförü kalabalık bir sokakta öne geçmek için durmadan korna çalar. Bu manzarayı asık suratla seyreden Vietnamlı bir genç "Mağrur Fransızlardan farkı yok" diye söylenir."21

1968 y1lına gelindiğinde savaş şiddetini artırmış ve bu da gazetenin sütunlarına yansımıştır. Yine hemen hergün savaşla ilgili ayrıntılı haber çıkmıştır. ABD'nin bu savaşta haksız olduğu okuyucuya hissettirilmiştir. Özellikle Kuzey Vietnam'ın barış için daha çok çabaladığı gazete sütunlarında s1k s1k verilen haberlerle belirtilmiştir. ${ }^{22}$

Ama tarafsılılk çizgisinden çıkmamak için ABD lehine yapılan yorumlara da yer verilmiştir. ${ }^{23}$

"En kanlı yıl"24 başlığı altında verilen haberde Vietnam'da durumun ciddi ve kötü olduğu anlatılmış ve okuyucunun dikkati çekilmeye çalışılmıştır.

Bu savaşın ABD'nin haksız istekleri doğrultusunda olduğunu belirtmek için, ABD'nin kendi ordusunun askerlerinin de bu haksız savaşa karşı oldukları ve savaştan kaçmaya başladıkları haberleri verilmiştir. ${ }^{25}$ Böylece ABD aleyhine yorumlar ABD haber kaynaklı verilerek, hem tarafsızlık ilkesinde çıkılmamış, hem de ABD'nin haksızlığ 1 başkalarının yorumlarıyla okuyucuya yansitılmıştır.

Sadece savaşan askerlerin değil, ABD halkının ve önemli isimlerinin de savaşa karşı olduğu verilen haberlerle okuyucunun dikkatine sunulmuştur. ${ }^{26}$

\section{c. Savaşın Dönüm Noktası}

Kuzey Vietnam ve Vietkong gerillalarının Tet Saldırısı, savaşın dönüm noktasını oluşturmuştur. ABD yönetimi, askeri bir zaferin imkansız

21 "Vietnam'da Neler Oluyor?”, Ulus Gazetesi, 8 Ocak 1965.

22 "Kuzey barış için saldırının durması teklifinde direniyor", Ulus Gazetesi, 5 Ocak 1965; "Kuzey Vietnam şartlı barış görüşme teklifini tekrarladı”, 14 ocak 1965.

23 "Hanoi'nin teklifi ustaca bir manevra mı?", Ulus Gazetesi, 6 Ocak 1965.

24 “En Kanl1 Y11", Ulus Gazetesi, 8 Ocak 1965.

25 "Vietnam' da bir Amerikan birliği kumandaya karşı baş kaldırdı", Ulus Gazetesi, 12 Ocak 1965. Ocak 1965.

"Fulbright'a göre Johnson'un Vietnam siyaseti başarıya ulaşmaz", Ulus Gazetesi, 23 
olduğunu anlamıştır. Ulus gazetesi de bu sıcak gelişmelere sütunlarında oldukça geniş yer vermiştir.

$\mathrm{Bu}$ gelişmelerle birlikte savaşın seyrinin değiştiğini gazete de verdiği haberlerle okuyucuya yansitmıştır.

Vietnam Savaşı ile ilgili köşe yazarlarının yorumunun dışında 2 ayrı yazı dizisi verilmiştir. Douglas Pike ve Doç Dr. Haluk Ülman yazı dizileri ile, Prof. A. Şükrü Esmer de köşe yazılarıyla Vietnam Savaşı'nı ele alıp, önemli yorumlar yapmışlardır..

Douglas Pike, ABD Haber Teşkilatına mensup, Güney Vietnam Ulusal Kurtuluş Cephesi hakkında incelemeleri olan ve Vietnam'da uzun yıllar çalışan bir isimdir. Yazarın yaptığı yorumlar savaşın bir kazananı olmayacağ1 yönündedir. "Saldırıların sonu Ne Olacak?"27 adlı yazısında önemli tespitlerde bulunmuştur.

Bir başka yazı dizisi olan Doç Dr. Haluk Ülman, politikaya atıldığı 1973-1980 yılları bir yana bırakılırsa, kırk yıllık bir akademik geçmişi olan akademik yaşamını, 1957 yılında siyasi tarih asistanı olarak başladığı aü siyasal bilgler fakültesi'nde önce asistan, sonra doçent, sonra da profesör olarak sürdürdü. 1973-1980 yılları arasında CHP'den İstanbul milletvekilliği yapt1. 1980 darbesinden sonra politikadan ayrilarak İstanbul'a, Marmara Üniversitesi İktisadi ve İdari Bilimler Fakültesi'ne geçti. 1981'den 1995'e kadar bu fakültenin İngilizce Uluslararası İlişkiler Bölümü'nün kurucu başkanlığını yaptı. 1996 yılından bu yana, Yeditepe Üniversitesi İletişim Fakültesi Dekanlığını yürütüyor ve aynı üniversitenin yüksek lisans programında "Uluslararası İlişkiler " ve "Türk Dış Politikası" derslerini veriyor. kitaplarının yanı sıra bilimsel dergilerde yayımlanmış çok sayıda makalesi de vardir.

ABD'ye ve onun emperyalizmine tamamen karşıdır. Yazılarında sık sık ABD'nin “domino teorisi”ne değinmiştir. Vietnam'daki komünistliği anlamak gerektiğini bizim bağımsızlık savaşımızı örnek göstererek açıklamaya çalışmıştır. Bu savaşın nasıl biteceğini de "Bu Savaş Nasıl Biter?" 28 yazısıyla yorumlamaya çalışmıştır.

Gazetenin uzun yıllar köşe yazarlığını yapmış olan Prof. A. Şükrü Esmer, Vakit gazetesi adına birinci dönem Lozan Barış Anlaşması görüşmelerini takip eden, 1949-1950 yılları arasında basın yayın genel müdtürlüğü yapan, zamanın Ulus Gazetesinde dış politika yazıları yazan eski

\footnotetext{
27 "Saldırının Sonucu Ne Olacak?", Ulus Gazetesi, 4 Mart 1968.

28 "Bu Savaş Nasıl Biter?”, Ulus Gazetesi, 17 Şubat 1968.
} 
gazeteci ise savaşın gidişatı ve sonucu ile alakalı en sağlam tespitleri yapan isim olmuştur.

Artık ABD'nin haksızlığı, satır arası verilen haberlerle ve farklı örneklerle vurgulanmaya başlanmıştır. $\mathrm{Bu} \mathrm{da}$, artık tarafsızlık politikasında çizginin dışına çıkıldığını gösterir. Mesela “ABD'nin Kuzey Vietnam'a yağdırdığı bombalar, II. Dünya Savaşı'nda Almanya'ya atılan bombalardan daha fazladır." başlıklı bir haberle savaşın dehşeti ve haksızlığı dile getirilmiştir.

Tarafsızlık çizgisinden çıkmakla birlikte, ABD halkının da olayları şaşkınlıkla izlediğine dair haberler verilerek, bir anlamda doğru ve olması gereken tarafta olunduğu kanıtlanmaya çalıșılmıștır. Ayrıca Amerikan kamuoyunun giderek savaş aleyhtarı olduğu da verilen dış kaynaklı haberlerle s1k s1k vurgulanmıştır. Örneğin "Amerika'da Vietnam Savaşı Aleyhtarlığ 1 Gittikçe Genişliyor" başlıklı haberde Amerikan kamuoyundan haberlere yer verilmiştir. "...Kararsızlık, şüphe ve endişenin ülkeyi sardığının delilleri çoktur. Mesela birkaç hafta öncesine kadar şöyle bir cümle, solcu bir dergi hariç bir yayım organı için düşünülemezdi:

"Amerikan halkının, hala hazır değilse, bütün Vietnam çabasının akamete uğramaya mahkum olduğuna artık hazırlanması gerektiği inancindayiz...(Wall Street Journal, 23 Şubat 1968)"

Gene aynı şekilde şöyle bir cümle de, solcu bir dergi dışındaki dergiler için birkaç hafta öncesine kadar düşünülmeyecek bir şeydi:

“Amerika'nın Vietnam'da dosttan çok düşmanı olduğu aşikardır. Amerikan askerlerinin durumu, İkinci Dünya Savaşı'nın son yıllarında Fransa'daki Alman işgal ordusunun durumunu andırmaktadır... (Background for Tomorrow, Lawrence Griswold)",29

Amerikalıların savaştaki vahşi tutumları ilgi çekici resimlerle birlikte okuyucuya verilmiştir. ${ }^{30}$ Amerika'nın giderek savaşta nükleer silah kullanacağ1 s1k sık manşet haber olarak verilmiştir. ${ }^{31}$

\section{d. Barış Görüşmeleri}

Tet Saldırısından sonra askeri bir zaferin imkansız olduğunu anlayan ABD yönetimi, 13 Mayıs 1968 'de Hanoi ile görüşme masasına oturmuştur.

29 “Amerikan halkı olayları dehşet ve küçülme hissiyle izliyor”, Ulus Gazetesi, 4 Şubat 1968; “Amerika'da Vietnam Savaşı Aleyhtarlığı Gittikçe Genişliyor”, Ulus Gazetesi, 2 Mart 1968.

30 “Amerikalıların esirlere karşı vahşi tutumu yerildi”, Ulus Gazetesi, 4 Şubat 1968.

31 "Vietnam'da nükleer silah kullanımı", Ulus Gazetesi, 13 Şubat 1968. 
Barış görüşmeleri Paris’te başlamıştır. Paris’teki işçi ve öğrenciler ABD'yi protesto etmişler ve bu da gazete tarafindan ayrıntılı olarak takip edilip, okuyuculara haber olarak iletilmiştir. ${ }^{32}$

$A B D$ ve Vietnam Demokratik Cumhuriyeti arasında geçen görüşmeler, iki tarafın da geri adım atmamasıyla kesintiye uğramıştır.

Barış görüşmesinin başlıca iki konusu: Bombardımanın durması ve askerden arınmış tarafsız bölge. Bu konularda anlaşılamayınca görüşmeler olumsuz gelişmiştir. ${ }^{33}$

$\mathrm{Bu}$ görüşmelerden iki tarafın da menfaati doğrultusunda sonuç çıkmayınca savaş devam etmiştir. Ancak ABD yeni strateji doğrultusunda Güney Vietnam'daki askerlerini yavaş yavaş geri çekmeye başlamıştır. ${ }^{34}$

$\mathrm{Bu}$ arada Ulus gazetesi 1971 yılından sonra yayın hayatına "Barış" olarak devam etmiştir.

1973 yılına gelindiğinde, ABD Güney Vietnam'daki asker sayısını azaltmasına rağmen bu savaştan kolay kolay vazgeçmek niyetinde değildi. Ancak hem kendi halkının, askerinin ve basınının verdiği tepkiler hem de Kuzey Vietnam'ın askeri başarıları ABD'yi geri adım atmaya zorlamıştır.

ABD yönetimi halkının tepkisini önlemek için basına sansür koymasına rağmen bu tepkilerin çoğalmasını engelleyememiştir. ${ }^{35}$

1973 yılı, hem savaşın son şiddetini yaşadığı hem de barışın adım adım geldiği yıl olmuştur. Barış gazetesi de artık tarafsızlık politikasından çıkıp, ABD karşııtı haberler vermeye başlamıştır. ${ }^{36}$

Neticede Paris'te başlayan barış görüşmeleri bir anlaşmayla sonuçlanmıştır. Buna göre; 28 Ocak 1973'ten itibaren Kuzey ve Güney Vietnam'da ateşkes yürürlüğe girecek, bütün ABD kuvvetleri çekilecek, üsler sökülecek, bütün savaş tutsakları serbest bırakılacak, bölge barışı uluslararası kuvvetlerce korunacak, Güney Vietnam'in kendi kaderini tayin etme hakk1 verilecekti. Bu anlaşmaya, Haziran 1973'de 14 maddelik ikinci bir anlaşma eklenmiştir. ${ }^{37}$

$\mathrm{Bu}$ anlaşmadan sonra savaşlar sona ermemiştir. Kuzey Vietnam Güney'i ele geçirmek için bütün gücüyle uğraşmış, nihayetinde Güney Vietnam 30 nisan 1975 'de yönetimi Kuzey Vietnam'a bırakmak zorunda

\footnotetext{
32 "Paris'te hayat durdu", Ulus Gazetesi, 14 Mayis 1968.

33 "Paris görüşmeleri olumsuz gelişiyor", Ulus Gazetesi, 20 Mayıs 1968.

34 “ilk ABD Askerleri Vietnam'dan Ayrildı", Ulus Gazetesi, 9 Temmuz 1969.

35 “ABD'de basina sansür kondu", Barıs Gazetesi, 7 Ocak 1973.

36 "Çirkin Savaş", Barış Gazetesi, 8 Ocak 1973.

37 “ẢBD Vietnam’dan kesinlikle çekiliyor”, Barış Gazetesi, 21 Ocak 1973.
} 
kalmıștır. Geçici bir askeri yönetimin kurulmasından sonra, 2 Temmuz 1976'da ülke resmen Vietnam Sosyalist Cumhuriyeti adiyla yeniden birleşmiş ve Hanoi başkent olmuştur.

\section{e. Ulus Gazetesinin Haber Aldığı Ajanslar}

"Anadolu Ajans1"

Moskova "Tass Ajansi"

"FLN Ajansı" (FLN: Vietnam Ulusal Kurtuluş Cephesi)

"Kuzey Vietnam Basın Ajans1"

"Bulgar Haber Ajansi"

\section{SONUÇ}

Söz konusu çalışmayı yapmaya başlamadan belirlediğimiz sorular çerçevesinde gazetemizi inceledik ve yaptığımız çalışma sonucunda o belirlediğimiz ve çalışmanın başında verdiğimiz sorulara şu cevapları bulduk:

Savaşın başından sonuna kadar gazetenin aldığı haber kaynakları ciddi ve güvenilir kaynaklardır. Dış kaynaklı haber ajanslarından faydalanan gazete, yayınladığı haberlerde sadece ajans ismi vermiş, muhabir adı vermemiştir. Yani sadece dış ve iç kaynaklı ajanslardan aldığı haberleri okuyucusuna sunmuştur. Vietnam Savaşı ile ilgili yazılan araştırma eserleriyle karşılaştırıldığında haberlerin doğru ve düzenli olarak okuyuculara verildiği görülmektedir.

Gazete, genel olarak bu savaşla ilgili belirlediği çizgiden çok fazla dışarı çıkmamıştır. Bir süre tarafsız gibi görünse de verdiği haberlerden taraf olduğu anlaşılmaktadır. Bu taraflığını açıkça ortaya koyup okuyucu yönlendirmemiştir. Buna karşıllk Ulus Gazetesi'nin Amerikan aleyhtarı olduğunu verilen haber ve yapılan yorumlardan çıkartmak zor değildir. Özellikle 1971 yılından sonra Barış Gazetesi olarak yayın hayatına devam ettiğinde daha taraflı ve okuyucu yönlendirici haberler vermeye başlamıştır. Gazete genel olarak dünya kamuoyu ve basınının ABD karşıtı haberlerini yorumsuz olarak vermiştir. Böylece kendisinin de ABD karşıtı olduğunu fakat bunu tarafsızlık politikasından çıkmamak kaygısıyla başkalarının aracılığıyla yansıttığını görmekteyiz. Ancak savaşın başladığı ilk dönemlerde, belki de iktidar partisinin CHP olmasından kaynaklı, hükümetin ABD'yi haklı bulmasından dolayı gazete de ABD'yi haklı bulur ifadeler kullanmıştır. 
Gazetede çıkan köșe yazıları ve savaşla ilgili yazı dizilerinin yaptığı yorumlar, savaşın gidişatı ve sonucu ile alakalı isabetli yorumlar yapabilmiştir. $\mathrm{Bu}$ köşe yazıları ve yazı dizileri manşet haberlerinden çok daha cesur ve yanlı yorumlar yapmışlardır. $\mathrm{Bu}$ köşe yazılarına yer vermesinden de gazetenin $\mathrm{ABD}$ aleyhtarı olduğu yorumunu çıkartabiliriz.

Gazete yaklaşı on yıl boyunca Vietnam Savaşı ile ilgili ayrıntılı ve düzenli haberler vermiştir. Haberlerin kesintiye uğradığı dönemler genelde Türkiye için önemli gündem konularının olduğu dönemlere denk gelmiştir. (Kıbrıs sorunu gibi) Bunun dışında savaşla ilgili hemen her gün haberlerin çıkması, Türk kamuoyunun da savaşla ilgilendiği ortaya koymaktadır.

\section{KAYNAKÇA}

Ana Britannica Ansiklopedisi, İstanbul 1994, Cilt 31, Hürriyet Yayınları

A'dan Z'ye Kurtuluş Savaşı ve Atatürk Dönemi, Komisyon, Boyut Yayınları, İstanbul 2005

ARMAOĞLU, Fahir, 20. Yüzyıl Siyasi Tarihi (Cilt 1-2:1914-1995), Alkım Yayınları, İstanbul 1999

GIAP, V.N., Vietnam Halk Savaşı, Çeviren: Mehmet Tunç, Bilim Ve Sosyalizm Yayınları, Ankara 1999

KOCABAŞOĞLU, Uygur, "Cumhuriyet Dergiciliğine Genel Bir Bakış", Türkiye'de Dergiler ve Ansiklopediler 1849-1984, Gelişim Yayınları, İstanbul 1984

MUTLU, Mustafa, Vietnam'dan Körfez Savaşı'na Uluslararası Uyuşmazlıklarda Kamuoyu Oluşumu, Basılmış Doktora Tezi, İstanbul Üniversitesi 2001

NEALE, Jonathan, Tarkan, Doğan, Amerikan Savaşı Vietnam 1960-1975, Metis Yayınları, İstanbul 2004

ÖZDEK, Refik, Vietnam Çıkmazı, Yağmur Yayınevi, İstanbul 1968

ÖZSELÇUK, Nusret, Ana Hatlarıyla Vietnam Savaşları ve Alınan Dersler, Genelkurmay Askeri Tarih ve Stratejik Etüt Başkanlığı Yayınları, Ankara 1979

SANDER, Oral, Siyasi Tarih 1918-1994, İmge Kitapevi, İstanbul 1998

Barış Gazetesi, 1971-1972-1973

Ulus Gazetesi, 1964-1965-1966-1967-1968-1969-1970-1971 


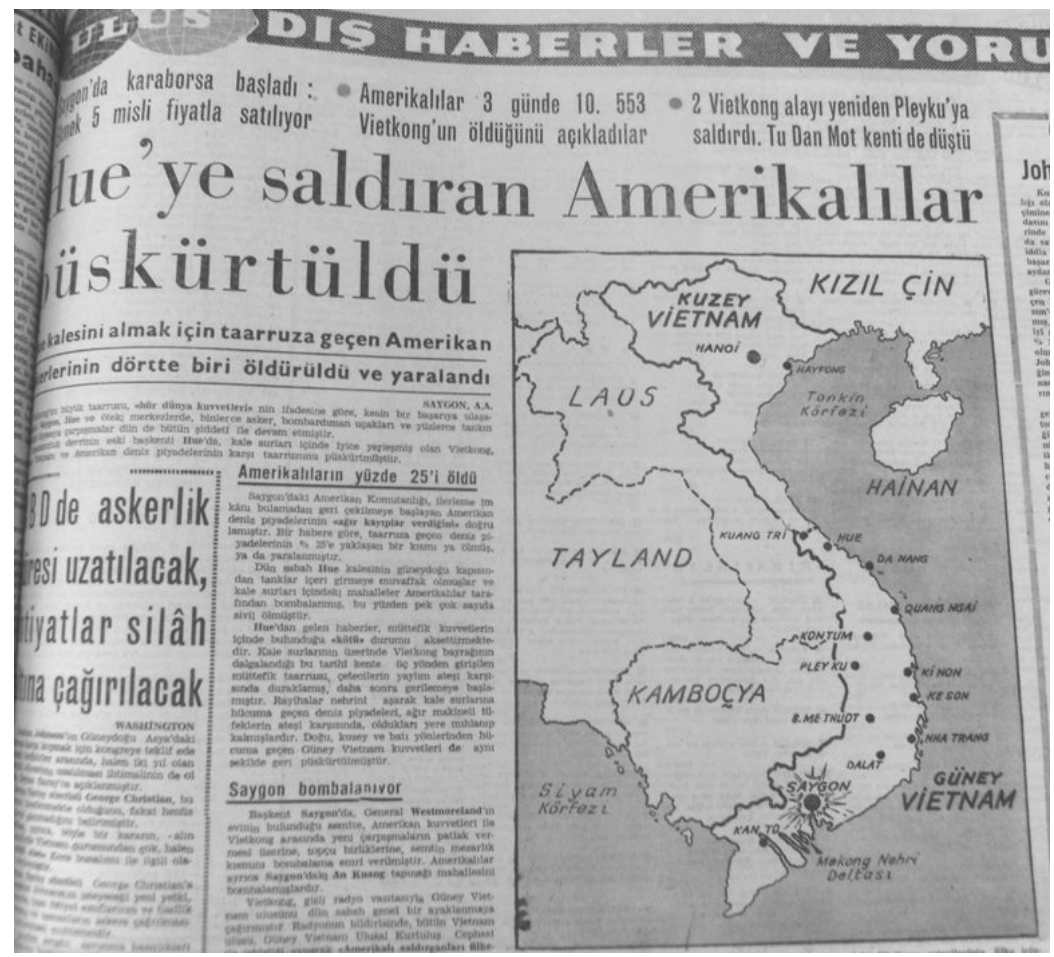



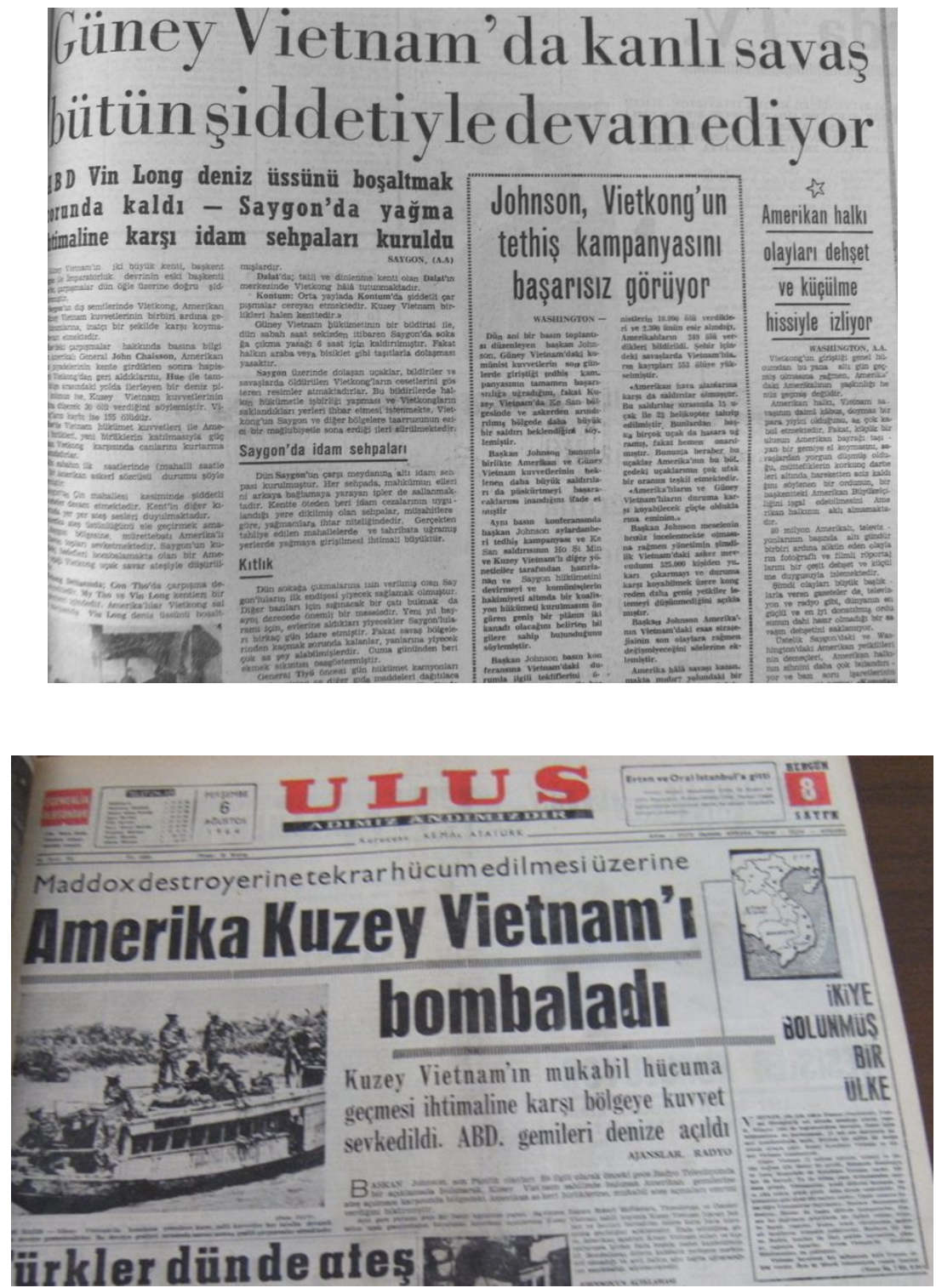


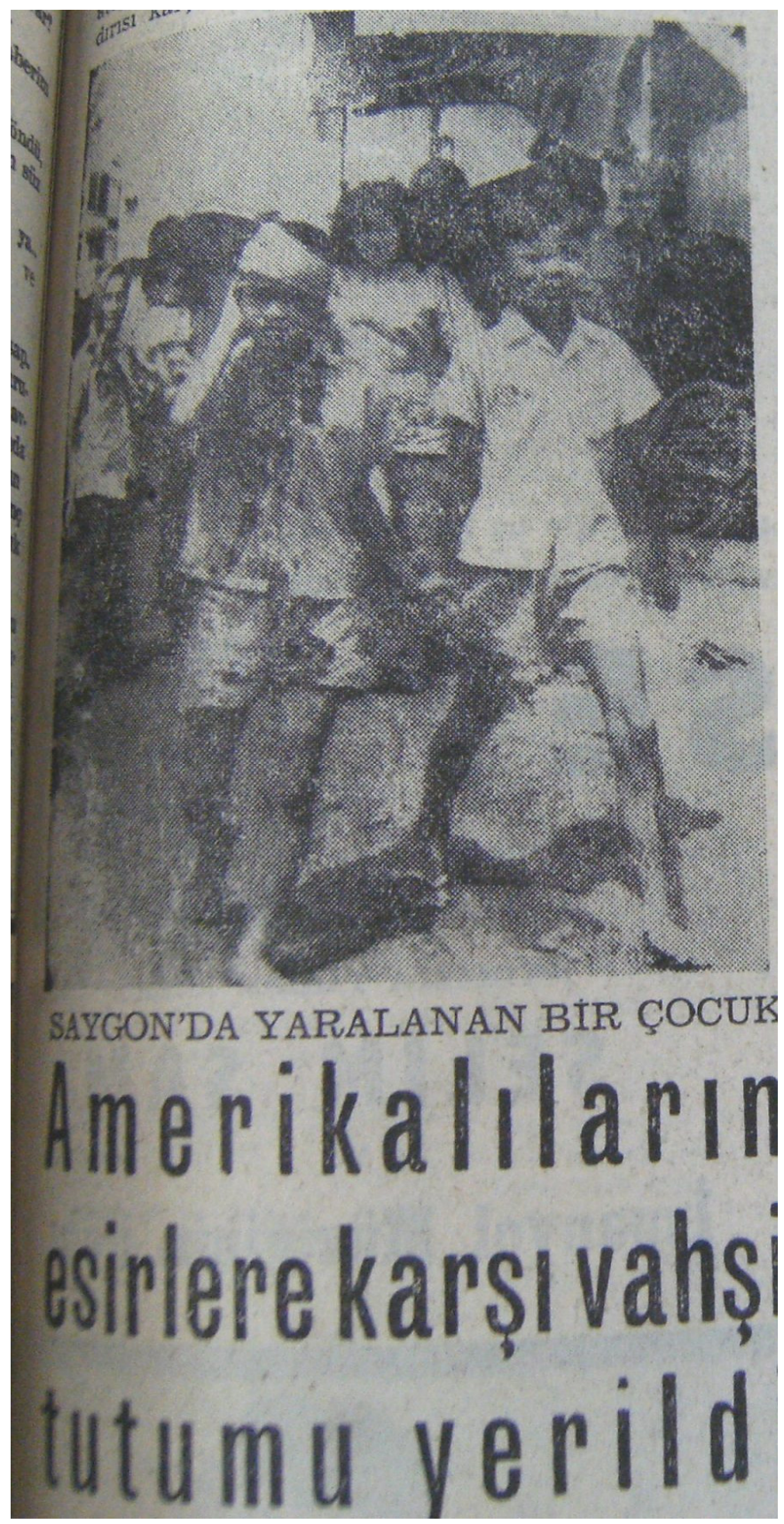




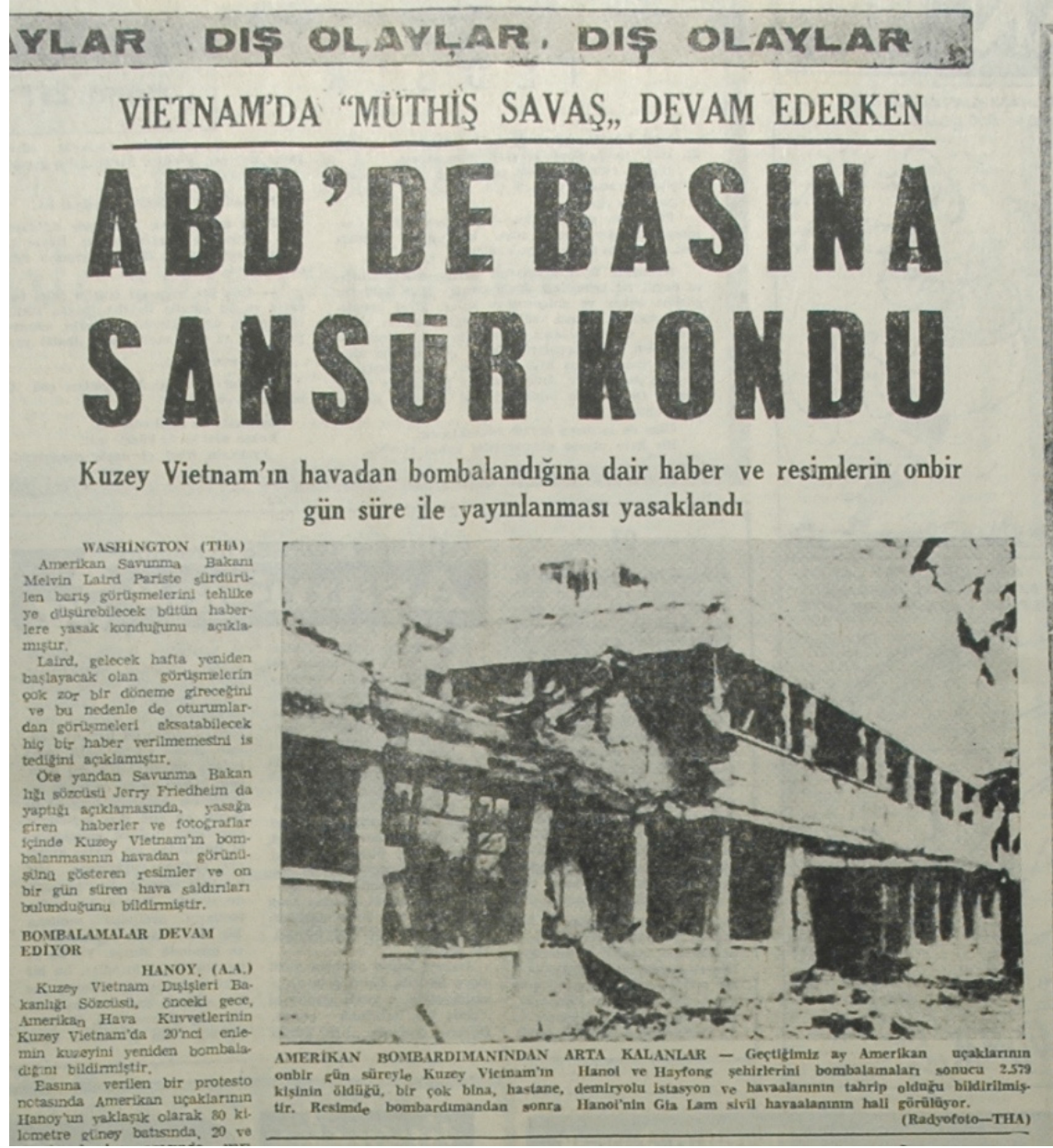




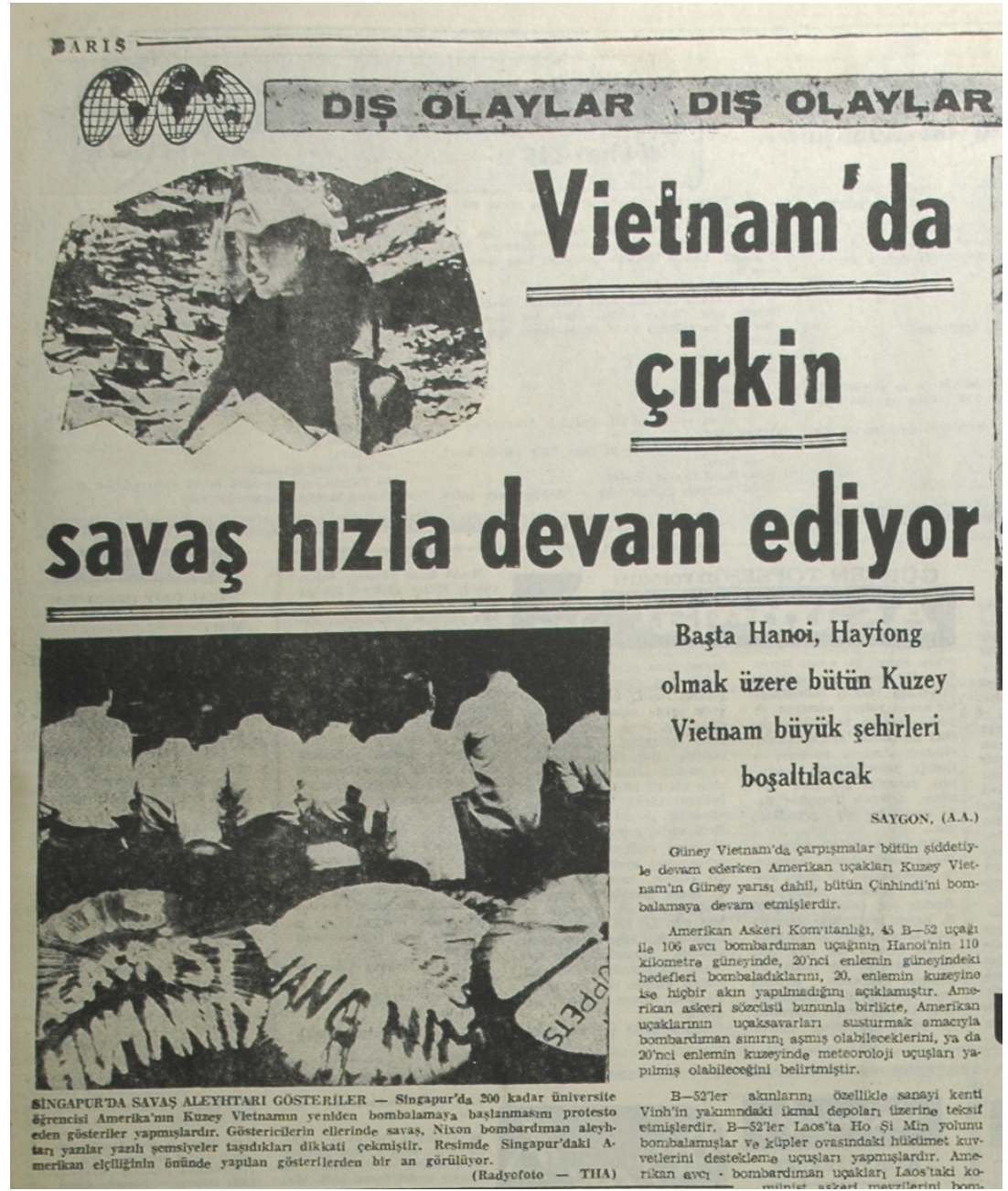




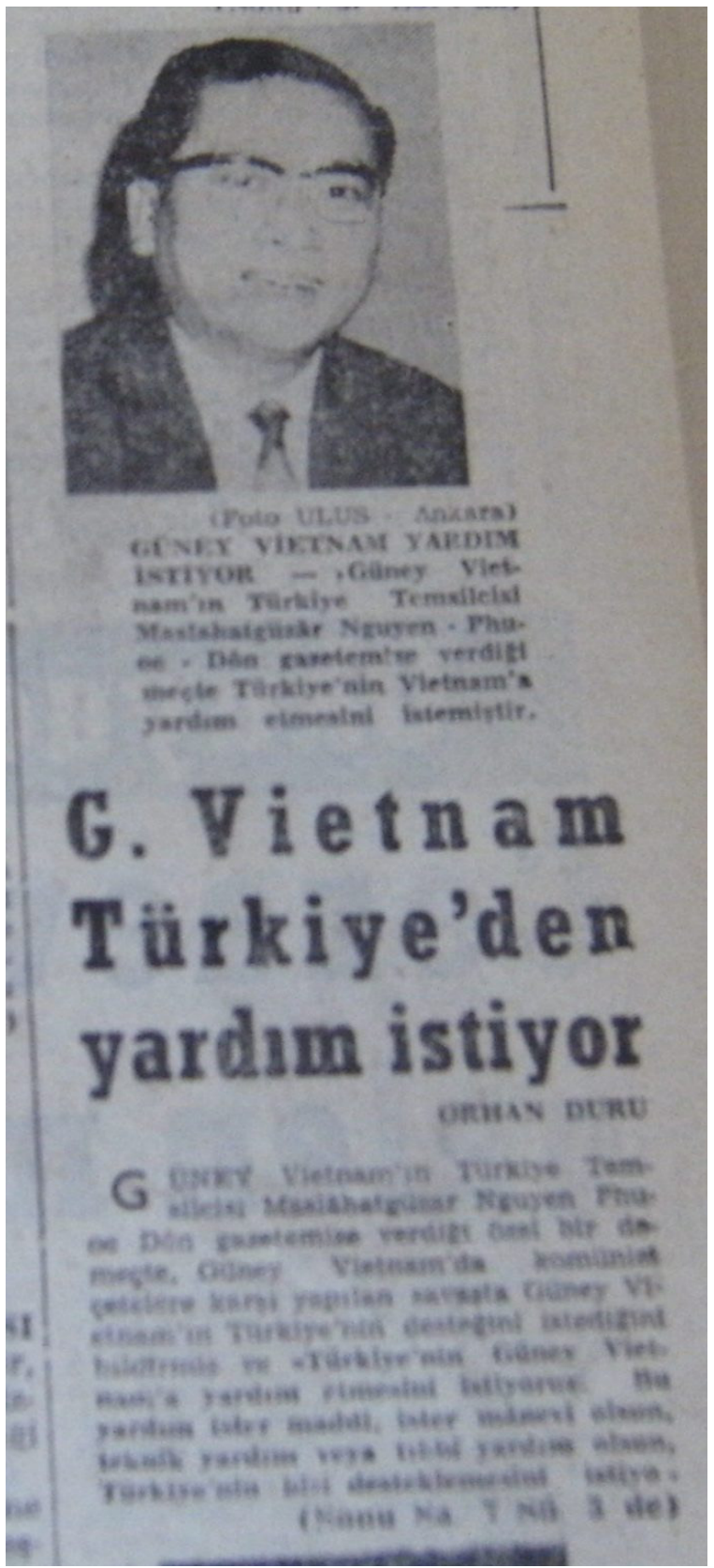




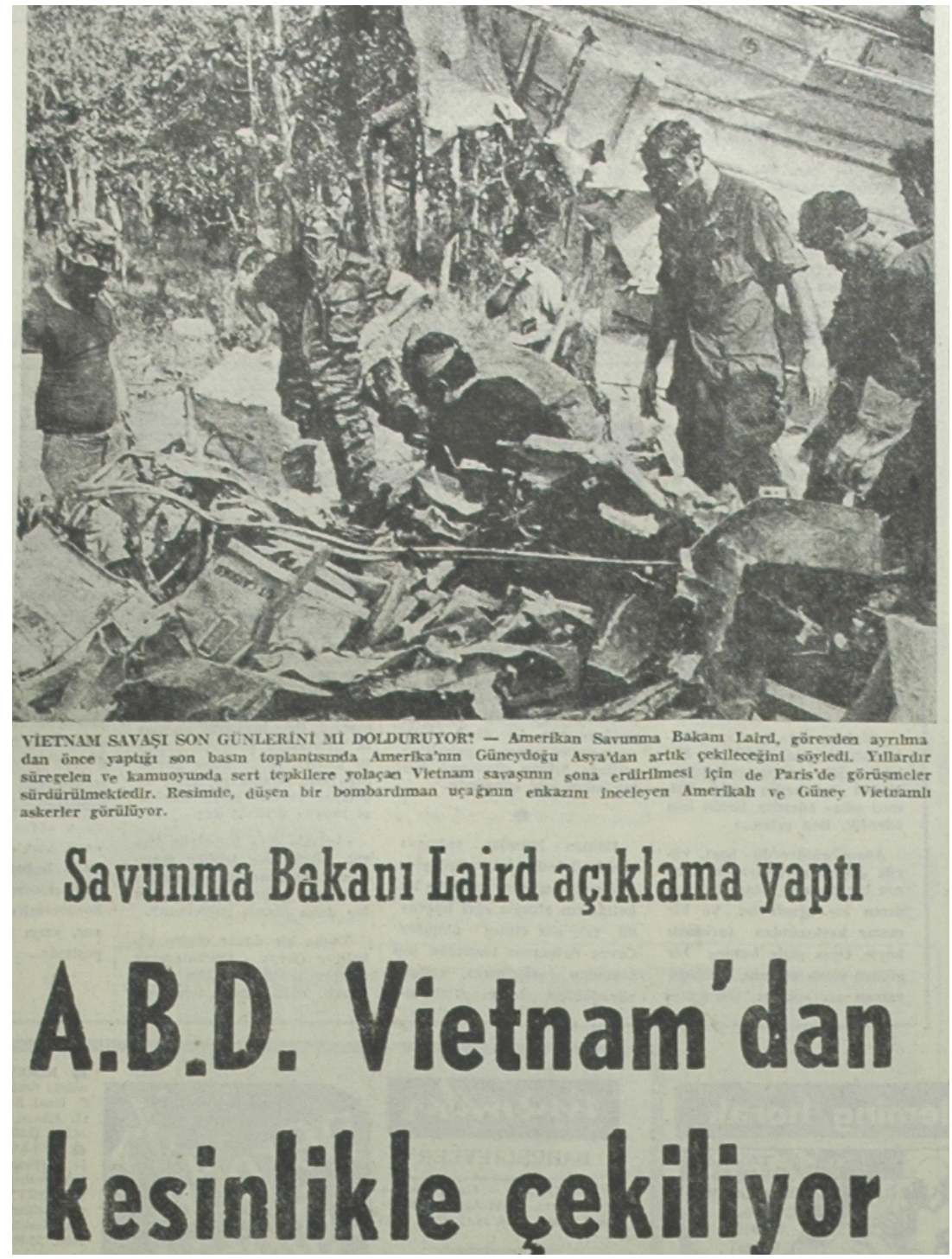




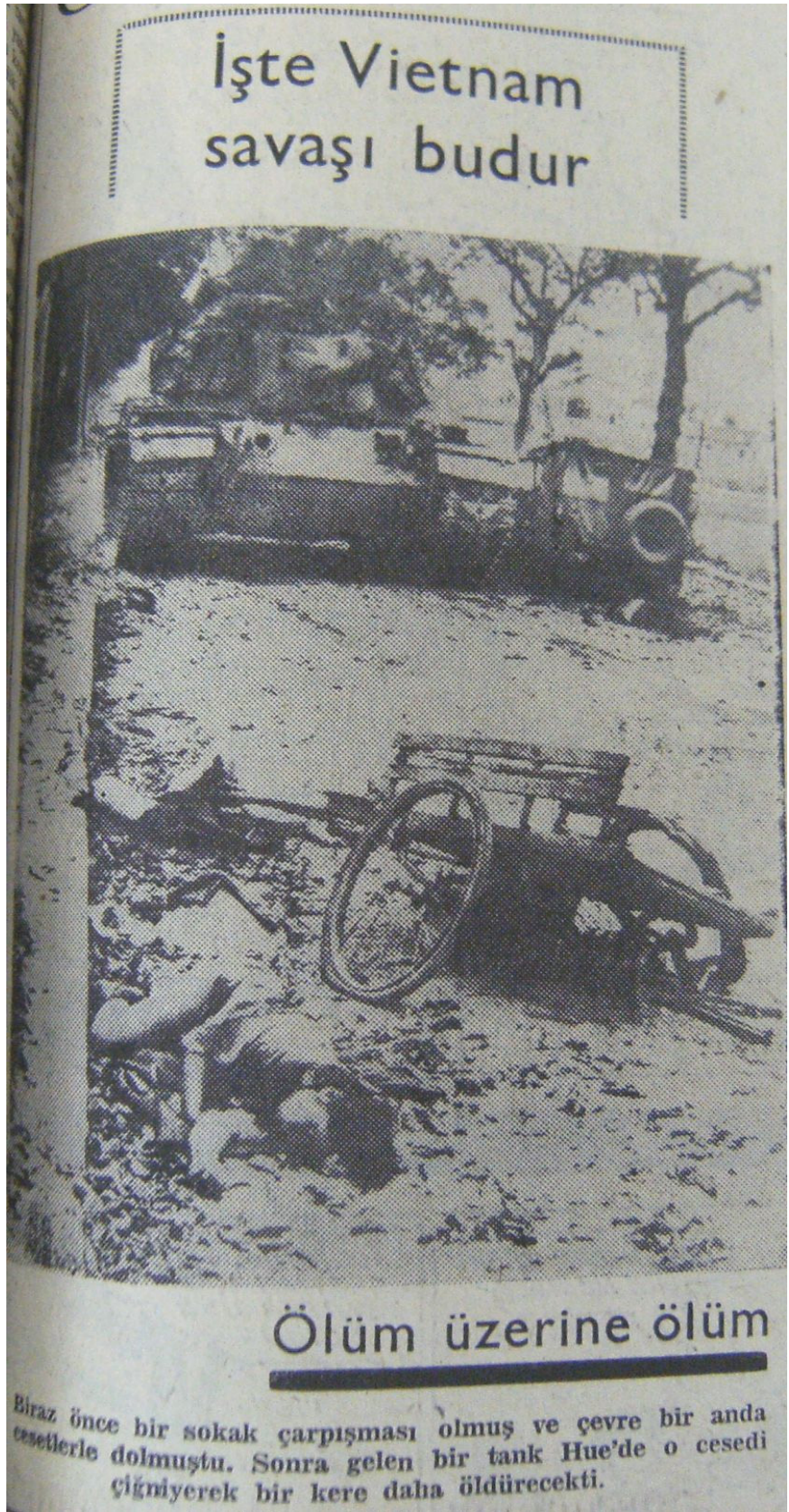

